\title{
Prostitution in Sheffield: differences between prostitutes
}

\author{
P D WOOLLEY, C A BOWMAN, G R KINGHORN \\ From the Department of Genitourinary Medicine, Royal Hallamshire Hospital, Sheffield
}

SUMMARY This study to assess differences between street walking prostitutes and sauna girls who attended this clinic in 1986 and 1987 showed that fewer street walkers used barrier methods for disease prevention with clients or accepted tests for antibody to human immunodeficiency virus (HIV) when offered and more street walkers practised their profession in both Sheffield and London. They therefore represent a potential pathway for the heterosexual spread of HIV to the region.

Trichomonas vaginalis was the only organism more commonly isolated from street walkers. Other sexually transmitted diseases diagnosed, and the sources of acquisition of gonococcal cervicitis, were similar in both groups of prostitutes. Prostitutes rarely used barrier methods with their regular consorts, who were found to be responsible for most cases of gonorrhoea in both groups.

As 11 out of 58 prostitutes attending were found to have dysplasia on routine cervical cytological examination, we suggest that all prostitutes be advised to undergo cytology yearly.

Prostitution is recognised as a form of high risk behaviour important in the heterosexual spread of human immunodeficiency virus (HIV). ${ }^{12}$ In Africa HIV transmission from infected prostitutes is promoted by concomitant sexually transmitted diseases (STD). ${ }^{3}$ Previous studies have emphasised the role of prostitutes in the spread of gonorrhoea, but have not looked at possible differences between prostitutes concerning their mobility, disease prevention behaviour, and acceptance of screening for HIV antibody. ${ }^{4-6}$ Such differences may reflect a variable potential for HIV acquisition and transmission in different prostitute groups.

The aims of this retrospective study were to assess what proportion of heterosexually acquired gonorrhoea in 1983-7 was attributed to prostitutes and also to investigate the demographic characteristics and genital infections diagnosed in prostitutes who attended this clinic in 1986 and 1987 , to provide baseline data on which to develop or modify health education efforts aimed at controlling STD.

\section{Patients and methods}

To assess the contribution that prostitutes have made to locally diagnosed gonorrhoea we investigated the

Address for reprints: Dr P D Woolley, Department of Genitourinary Medicine, Royal Hallamshire Hospital, Sheffield S10 2JF

Accepted for publication 10 July 1988 case records of all heterosexual men attending with acute gonococcal urethritis in 1983-7 to find out how many infections were acquired from prostitutes.

We also reviewed the case records of all women prostitutes attending the clinic in 1986 and 1987 . We identified two groups: street walkers (women who seek clients in public places or who walk the streets) and sauna girls (women who practise prostitution from fixed premises or local massage parlours). In Sheffield prostitutes offer their services while working for fixed periods of time from premises advertised openly and in the local press as saunas. Girls often operate from several different establishments. Street walking prositutes operate predominantly from two districts in Sheffield that are well known to the clinic and the general public. Within this group there is surprising comradeship. We know of no escort agencies in Sheffield.

Since the campaign to increase public awareness regarding AIDS, we have encouraged sauna girls to attend by contacting the saunas direct and have relied on counselling street walkers to offer them regular screening for STD and provide education regarding barrier methods to prevent the acquisition of disease. We have also offered open access to the department and the free provision of condoms. We compared the two groups regarding their demographic characteristics, contraceptive practices, use of condoms for disease prevention before their initial attendance, acquisition of sexually transmitted genital infections 
Table 1 Yearly numbers of men with gonorrhoea acquired from prostitutes/numbers with gonococcal urethritis comparing locations where infection acquired

\begin{tabular}{llllllc}
\hline & 1983 & 1984 & 1985 & 1986 & 1987 & Total (\%) \\
\hline Sheffield & $2 / 198$ & $1 / 285$ & $3 / 300$ & $3 / 305$ & $1 / 101$ & $10 / 1189(1)$ \\
London & $1 / 4$ & $0 / 11$ & $0 / 4$ & $3 / 9$ & $1 / 3$ & $5 / 31(16)$ \\
Elsewhere in the United Kingdom & $0 / 44$ & $0 / 50$ & $3 / 54$ & $1 / 61$ & $0 / 26$ & $4 / 235(2)$ \\
Overseas & $1 / 17$ & $1 / 16$ & $1 / 15$ & $1 / 15$ & $1 / 6$ & $5 / 69(7)$ \\
\hline
\end{tabular}

during the study period, and acceptance of HIV antibody testing.

We used the $\chi^{2}$ test for statistical analysis.

\section{Results}

Table 1 shows that in 1983-7 the yearly number of men with locally acquired gonococcal urethritis attributed to prostitutes was small and seldom exceeded $1 \%$ of the total number of infections acquired in Sheffield. During the same five year period the total number of cases attributable to prostitutes in London was also small, but accounted for $16 \%$ of the total number of infections acquired in the capital.

A total of 82 prostitutes ( 29 street walkers, 53 sauna girls) attended the clinic in 1986 and 1987 . No significant difference was seen between the two groups of prostitutes in mean (SD) age (24.7 (5.9) years), number unmarried (77), number white (78), and number having had a termination of pregnancy (25). Table 2 shows the differences between the two groups. Some contraceptive method was practised by 25 $(86 \%)$ street walkers and by all 53 sauna girls. For disease prevention $20(69 \%)$ street walkers and 48 $(91 \%)$ sauna girls regularly used condoms $\left(\chi^{2}=4 \cdot 7\right.$; $\mathrm{p}<0.05$ ). No significant difference was seen between the two groups regarding the number with a regular consort (data not shown), previous clinic attendance, or history of gonorrhoea. Fewer street walkers (20

Table 2 Differences between street. walkers and sauna girls who attended Sheffield STD clinic in 1986-7 (figures are number (per cent) of prostitutes in each group)

\begin{tabular}{lcc}
\hline & $\begin{array}{l}\text { Street walkers } \\
(n=29)\end{array}$ & $\begin{array}{l}\text { Sauna girls } \\
(n=53)\end{array}$ \\
\hline Contraceptive practices: & & \\
Oral contraceptive & $11(38)$ & $23(43)$ \\
Intrauterine device & $2(7)$ & $6(11)$ \\
Sterilisation & $4(14)$ & $6(11)$ \\
Condom & $8(28)$ & $18(34)$ \\
None & $4(14)$ & 0 \\
Barrier methods used with clients: & $19(66)^{*}$ & $47(89)^{*}$ \\
Every client & $1(3)$ & $1(2)$ \\
Most clients & $9(31)$ & $5(9)$ \\
Never/occasional & $12(41)$ & $14(26)$ \\
Previously attended clinic & $15(52)$ & $27(51)$ \\
History of gonorrhoea & $20(69)^{*}$ & $48(91)^{*}$ \\
Accepted test for antibody to HIV & \\
\hline *p $<$ 0.05. & & \\
HIV = human immunodeficiency virus. &
\end{tabular}

(69\%)) than sauna girls (48 (91\%)) accepted HIV antibody testing when it was offered $\left(\chi^{2}=4 \cdot 7, p<\right.$ 0.05).

Table 3 shows differences between prostitutes in STD diagnosed during the study period. No significant difference was seen between the two groups in the numbers attending with acute gonococcal cervicitis, genital warts, chlamydial cervicitis, or pelvic inflammatory disease. Significantly more street walkers than sauna girls attended with trichomoniasis $\left(\chi^{2}\right.$ $=4.6, p<0.05)$. No difference was seen between the two groups in the source of acquisition of gonorrhoea.

Cervical cytology was undertaken for 58 of the prostitutes during the study period. Cone biopsy or laser treatment had been performed on a further four before 1986, and their follow up was undertaken at another hospital. Of those who underwent cervical cytology, $36(62 \%)$ were reported as having negative results, $11(19 \%)$ as having wart virus changes, 10 $(17 \%)$ as having mild to moderate dysplasia, and one $(2 \%)$ as having severe dysplasia. No difference was seen between the two groups in either the number with abnormal cytology results or the degree of severity.

During the study period $11(38 \%)$ street walkers also regularly worked on the streets of London,

Table 3 Sexually transmitted diseases diagnosed in prostitutes attending Sheffeld STD clinic in 1986-7

\begin{tabular}{|c|c|c|}
\hline & $\begin{array}{l}\text { Street walkers } \\
(n=29)\end{array}$ & $\begin{array}{l}\text { Sauna girls } \\
(n=53)\end{array}$ \\
\hline \multicolumn{3}{|l|}{ Gonorrhoea: } \\
\hline $\begin{array}{l}\text { No (\%) of women infected } \\
\text { No of episodes } \\
\text { No (\%) of episodes traced to: }\end{array}$ & $11(38)$ & $\begin{array}{l}12(23) \\
15\end{array}$ \\
\hline & $\begin{array}{r}10(59) \\
6(35)\end{array}$ & $\begin{array}{l}9(60) \\
4(27)\end{array}$ \\
\hline Not traced & $1(6)$ & $2(13)$ \\
\hline \multicolumn{3}{|l|}{ Chlamydial cervicitis } \\
\hline $\begin{array}{l}\text { No }(\%) \text { of women infected } \\
\text { No of episodes }\end{array}$ & $1_{11}^{6(21)}$ & $\begin{array}{l}14(26) \\
14\end{array}$ \\
\hline \\
\hline $\begin{array}{l}\text { No }(\%) \text { of women infected } \\
\text { No of episodes }\end{array}$ & $12(41)^{*}$ & $9(17)^{*}$ \\
\hline \multicolumn{3}{|l|}{ Pelvic inflammatory disease } \\
\hline $\begin{array}{l}\text { No }(\%) \text { of women affected } \\
\text { No of episodes }\end{array}$ & $2(7)$ & $2(4)$ \\
\hline \multicolumn{3}{|l|}{ Genital warts } \\
\hline $\begin{array}{l}\text { No }(\%) \text { of women infected } \\
\text { No of episodes }\end{array}$ & $2(7)$ & $\begin{array}{l}5(9) \\
5\end{array}$ \\
\hline
\end{tabular}


whereas only three $(6 \%)$ sauna girls also worked from fixed premises in the capital. Of the 11 street walkers who also worked in London, four failed to use barrier methods for disease prevention and three refused HIV antibody testing.

Although seven (35\%) street walkers attended for a check up because of condom failure compared with 10 $(21 \%)$ sauna girls, the difference was not significant. Of 15 street walkers and 31 sauna girls tested for hepatitis B surface antigen, none were found to be positive. No prostitute was found to be HIV seropositive.

\section{Discussion}

Compared with a previous study on prostitutes in Sheffield there has been a pronounced reduction in the number of cases of gonococcal urethritis acquired from local prostitutes. ${ }^{4}$ In the earlier study local prostitutes accounted for $27(12 \%)$ cases in 1968, 17 $(6 \%)$ cases in 1969, $21(6 \%)$ cases in 1970, $44(11 \%)$ cases in 1971 , and $36(10 \%)$ cases in 1972 . Further cases were attributed to local prostitutes, but the authors failed to identify whether these were infections of regular consorts. Although we cannot assume that all men acquiring gonorrhoea from prostitutes will pass this information to the doctor, our study is comparable with the previous one.

There were many similarities in demographic characteristics, although there were several differences in behaviour between the two groups of prostitutes that we studied. Fewer street walking prostitutes than sauna girls used barrier methods for disease prevention or accepted HIV antibody testing when offered, and more practised their profession in both Sheffield and London. This represents a potential pathway for the heterosexual spread of HIV to the region.

The yearly incidence of gonorrhoea in prostitutes is proportional to the number of attendances, and the numbers of infected prostitutes have therefore varied (9\% in Singapore, ${ }^{5} 36 \%$ Vienna, ${ }^{6}$ 28\% Fresno County, ${ }^{7} 100 \%$ Sheffield $\left.{ }^{4}\right)$. The pattern of sexually transmitted genital infections diagnosed and the source of acquisition of gonorrhoea were surprisingly similar in both groups of prostitutes, considering their differences in the use of barrier methods with clients. Prostitutes rarely use barrier methods with regular consorts, and regular sexual partners were therefore found to be responsible for most cases of gonorrhoea in both groups of prostitutes. It is not yet clear why $T$ vaginalis was the only organism more commonly isolated from street walkers. The incidence of $C$ trachomatis in both groups was higher than that found in the only previous study of this organism in prostitutes, ${ }^{8}$ and was also higher than in women attending a clinic for STD.?

About $10 \%$ of prostitutes may be expected to develop abnormal cervical cytological changes that require further investigation. ${ }^{10}$ We identified $11(19 \%)$ prostitutes with dysplasia during the two year study period and suggest that all prostitutes be advised to have yearly cervical cytological examination.

In three previous studies of hepatitis B surface antigen (HBsAg) in prostitutes, its incidence was found to be $3 \%,{ }^{11} 4 \%,{ }^{12}$ and $6 \%{ }^{13}$ in those tested. In our study no prostitute was found to be HBsAg positive, nor were any of 984 women attending the clinic who underwent hepatitis serology testing in conjunction with HIV antibody testing.

We have encouraged local prostitutes to attend for screening every three months by allowing open access to health workers and by offering condoms for disease prevention. Health education is currently being aimed at promoting the use of barrier methods, particularly by street walkers, to reduce the acquisition of disease in the short term, and possibly cervical cytological abnormalities in the long term. From our findings on the source of gonorrhoea it is important that regular consorts of prostitutes attend to have the infection excluded or treated.

\section{References}

1 Vittecoq D, May T, Roue RT, et al. Acquired immunodeficiency syndrome after travelling in Africa: an epidemiological study in seventeen caucasian patients. Lancet 1987;i:612-4.

2 Denis F, Barin F, Gershy-Damet G, et al. Prevalence of human Tlymphotropic retrovirus type III (HIV) and type IV in the Ivory Coast. Lancet 1987; i:408-11.

3 Biggar RJ. The AIDS problem in Africa. Lancet 1986;i:79-82.

4 Turner EB, Morton RS. Prostitution in Sheffield. British Journal of Venereal Diseases 1976;52:197-203.

5 Khoo R, Sng EH, Goh AJ. A study of sexually transmitted diseases in 200 prostitutes in Singapore. Asian Journal of Infectious Diseases 1977;1:77-80.

6 Fanta D, Gebhart W, Gross W, Kokoschka EM, Söltz-Szöts J, Thurner J. Results of routine screening for sexually transmitted diseases in Austria over a six year period. British Journal of Venereal Diseases 1979;55:147-8.

7 Jaffe HW, Rice DT, Voigt R, Fowler J, St John RK. Selective mass treatment in a venereal disease control program. Am J Public Health 1979;69:1181-2.

8 Darougar S, Aramesh B, Gibson JA, Treharne JD, Jones BR. Chlamydial genital infection in prostitutes in Iran. British Journal of Venereal Diseases 1983;59:53-5.

9 Burns DC MacD, Darougar S, Thin RN, Lothian L, Nicol CS. Isolation of Chlamydia from women attending a clinic for sexually transmitted disease. British Journal of Venereal Diseases 1975;51:314-8.

10 Keighly E. Carcinoma of the cervix among prostitutes in a women's prison. British Journal of Venereal Diseases 1968; 44:254-5.

11 de Hoop D, Anker WJJ, van Strik R, Masurel N, Stolz E. Hepatitis $B$ antigen and antibody in the blood of prostitutes visiting an outpatient venerology department in Rotterdam. British Journal of Venereal Diseases 1984;60:319-22.

12 Papaevangelou G, Trichopoulos D, Papoutsakis G, Kremastinou T, Pavlides E. Hepatitis B antigen in prostitutes. British Journal of Venereal Diseases 1974;50:228-30.

13 Goh CL, Kamarudin A, Chan SH, Rajan VS. Hepatitis B virus markers in prostitutes in Singapore. Genitourin Med 1985; 61:127-9. 